\title{
The Relationship between Organizational Culture and Organizational Commitment
}

\author{
Dima H. Aranki ${ }^{1}$, Taghrid S. Suifan ${ }^{1} \&$ Rateb J. Sweis ${ }^{1}$ \\ ${ }^{1}$ School of Business, The University of Jordan, Amman, Jordan \\ Correspondence: Dima H. Aranki, School of Business, The University of Jordan, Amman, Jordan. Tel: 962-6535- \\ 5000. E-mail: dima.aranki92@gmail.com
}

Received: January 7, 2019

Accepted: February 4, $2019 \quad$ Online Published: March 31, 2019

doi:10.5539/mas.v13n4p137

URL: https://doi.org/10.5539/mas.v13n4p137

\begin{abstract}
The main purpose of this research is to investigate the relationship between organizational culture and organizational commitment, in Information Technology (IT) companies in Jordan. A convenience sample was selected from employees working in 24 IT companies in Jordan. A total of 711 questionnaires were distributed among them; 371 were returned, and 342 were valid for statistical analysis, resulting in response rate of 52 percent. Linear regression analysis was also used to test the hypothesis. The results of the analysis indicated that there is a positive and significant relationship between organizational culture and organizational commitment. Based on the results, the research provides several recommendations. IT companies in Jordan should place emphasis on building better culture, in order to achieve higher levels of organizational commitment. The research also suggests that future research should take job satisfaction as a mediator variable of the relationship between organizational culture and organizational commitment.
\end{abstract}

Keywords: information technology companies, organizational commitment, organizational culture

\section{Introduction}

\subsection{Background}

Culture has been the focus of the work of many authors and anthropologists for a long time, as they have tried to understand different groups around the world. However, recently they have found a link between organizational culture, the behavior of people, and firms' performances (Warrick, 2017). Organizational culture grows via norms, and norms are an essential determinant of behavior (Bettenhausen \& Murnighan, 1985; Hogan \& Coote, 2014). Organizational culture specifies and indicates the common perceptions of a firm's employees, and affects their behavior (Ahmady, Nikooravesh, \& Mehrpour, 2016). They also consider it to be a very important factor for the success of any organization (Levering, 2016). Although organizational culture is not the only aspect in achieving organizational success, developing a culture supersedes these factors (Arditi, Nayak, \& Damci, 2017). Organizational commitment is a force that connect an employee to a course of action relevant to certain purposes (Meyer \& Herscovitch, 2001). As a result, committed employees become hard workers and more active; therefore, organizations with committed employees are more effective (Morrow, McElroy, \& Scheibe, 2012). Most others identify this concept as the strengths of individual implications and identifications in an organization (Stan, 2013). Organizational commitment is obtained when the firm and the employee have an interest in maintaining their working relationship (Tharikh, Ying, \& Saad, 2016). Therefore, this research is undertaken to examine the relationship between organizational culture and organizational commitment in IT companies in Jordan.

\subsection{Research Problem}

The literature on organizational culture, and organizational commitment is extensive (Siverthorne, 2004; Huey Yiing \& Zaman Bin Ahmad, 2009). Huey Yiing and Zaman Bin Ahmad (2009) examined the moderating role of organizational culture on the relationship between organizational commitment and job satisfaction in Malaysia. Al-Sada, Al-Esmael, and Faisal (2017) investigated the relationship between organizational culture and organizational commitment in Qatar. Silverthorne (2004) studied the effect of organizational culture on organizational commitment in Taiwan. Several studies have focused on culture in its broad sense (national culture), and its relationship with organizational commitment. Kwantes (2009) studied culture and organizational commitment in the United States and India. Abdul Rashid, Sambasivan, and Johari (2003) investigated the effect 
of organizational commitment and organizational culture on performance in companies of Malaysia. Odom, Boxx, and Dunn (1990) examined the influence of organizational culture on several elements of employee behavior: work-group cohesion, commitment, and job satisfaction. In addition, most of the studies in the organizational culture area have measured organizational culture as a supportive, innovative, and bureaucratic culture (Allen \& Meyer, 1990; Wallach, 1983). To the best of the researcher's knowledge, no study has included the employee empowerment measure with those measures. Based on the gap found in the literature, this research seeks to answer the following question:

What is the relationship between organizational culture and organizational commitment, in the IT companies in Jordan?

\subsection{Research Objectives}

The main purpose of this research is to examine the relationship between organizational culture and organizational commitment, in IT companies in Jordan. In particular, the research aims to achieve the following objectives:

1- To examine the relationship between organizational culture and organizational commitment.

\subsection{Importance of the Research}

Previous research shows the importance of organizational commitment because, when it does exist, it leads to different positive outcomes (Hanaysha, 2016a). Fostering it among employees is very important because employees who are committed to their organization will perform better, stay longer, become loyal, and be more productive (Dey, Kumar, \& Kumar, 2014). Organizational commitment is considered a significant issue, especially in management organization, because organizational commitment is related to organizational competiveness and profitability (Abdullah \& Ramay, 2012). Organizational culture has been considered a determinant of business success (Joseph \& Francis, 2015) and an indicator of organizational performance (Deshpandé \& Farley, 2004). The increasing importance of economy and the increasing number of born global companies make it useful to study how they achieve this huge success (Zhang \& Tansuhaj, 2007). Existing IT research shows that organizational culture affects IT companies (Harper \& Utley, 2001). There is little research into how organizational culture influences IT firms (Scholarios et al., 2008). Encouraging employees to do their best in their work in these situations is a huge challenge for IT organizations (Nohria, Groysberg, \& Lee, 2008). Therefore, understanding the factors that keep employees committed is an essential challenge for IT organizations (Messner, 2013). Remarkably, employee commitment and retention in small- to medium-sized IT companies is a matter of concern (Valaei \& Rezaei, 2016). IT services have now started to treat organizational commitment as a problem in any business, and not only as a human resource management issue (Adachi, Helfrich, Gretczko, \& Schwartz, 2012). Messner (2013) showed that organizational culture is central to all activities in the organization. Several studies have agreed on the positive relationship between organizational culture, and organizational commitment (Bellou, 2010; Messner, 2013). Therefore, the findings of this research may help IT organizations to try and recreate better and stronger cultures, and make them more committed to the firm and less disposed to leaving.

\section{Literature Review}

\subsection{Introduction}

A literature review of the research in organizational culture, its definitions and dimensions - supportive, innovative, bureaucratic culture, and employee empowerment - is undertaken in the first section. The second section discusses organization commitment and its dimensions - affective, normative, and continuance. Finally, the research discusses the relationship between these variables.

\subsection{Organizational Culture}

Many international researchers have agreed that the relationship between organizational culture and employees is key to the success of organizations (Cameron \& Quinn, 2011). Schein (199ㅁ), in defining culture, used the term group to define all sizes of social units in any study of organizational culture. Warrick (2017) used the group concept to describe the organization or group of people as being like a country or family, those groups of people who are likely to form a certain culture, and he referred to the culture of any group of people or whole organization that works together. Cultures are very different between and within organizations, where culture may bring the best or worst out of the employees (Warrick, Milliman, \& Ferguson, 2016). Cameron and Quinn (2011) said that through organizational culture we can distinguish between a successful company and a failing company. Some researchers have agreed that organizational culture is a complex issue in the workplace and in the world generally; it is directly connected to the performance and effectiveness of the firm, if the organizational culture is strong, the firm is more effective (Lapina, Kairiša, \& Aramina, 2015). Most discussions of organizational culture (Cameron \& Ettington, 1988; Schein, 1996) have agreed that culture is the 'social glue' that bind everyone in the organization 
together. Organizational culture also refers to collections of norms, beliefs, values, and essential claims shared by organizational employees and incorporates organizational goals, missions, practices, and policies (Hofstede, Neuijen, Ohayv, \& Sanders, 1990; Khazanchi, Lewis, \& Boyer, 2007). According to wallach (1983), organizational culture should be measured on the basis of three dimensions: supportive culture, innovative culture, and bureaucratic culture. Shahzad, Xiu, and Shahbaz (2017) measured organizational culture by employee empowerment.

\subsubsection{Supportive Culture}

A supportive culture reflects when employees work with teams, and when they encourage and trust each other (Wallach, 1983). Supportive cultures support open relationships among employees and contribute to a friendly workplace and employees that help each other (O'Reilly, Chatman, \& Caldwell, 1991). Supportive culture is characterized by collaboration, encouragement, and confidence in relations (Wallach, 1983). Berson, Oreg, and Dvir (2008); Burke, Sims, Lazzara, and Salas (2007) argued that supportive culture promotes a collaborative atmosphere that is helpful and friendly in general. There are many studies that show the relationship between supportive culture and organizational commitment; organizations with cultures that are supportive tend to have the highest levels of organization commitment (Silverthorne, 2004). Lok and Crawford (1999) also suggested that a supportive work environment could result in employees with a greater commitment than a bureaucratic culture.

\subsubsection{Innovative Culture}

An innovative culture refers to a workplace in which employees are creative, and an environment that is challenging (Wallach, 1983). This dimension involves an environment in which employees are seeking for opportunities, challenge, and risk, innovative culture is exciting and dynamic, while being full of challenges at the same time (Ireland, Hitt, \& Sirmon, 2003; Berson et al., 2008). Rasool, Ganai, Kamili, \& Akbar (2012) showed that innovative culture focuses on the internal systems of the firm and on its competitive advantage because it allows for openness to new ideas. There are many studies showing the relationship between innovative culture and organizational commitment. Silverthorne (2004) stated that organizations with innovative cultures tend to have a middle level of organizational commitment.

\subsubsection{Bureaucratic Culture}

Bureaucratic culture is compartmentalized, systematic, and organized, and has an intelligible lines of authority and responsibility, it also refers to a work environment which is regulated and procedural (Wallach, 1983). Organizations that apply this dimension emphasize consistency, and predictability (Wallach, 1983; Berson et al., 2008). In literature, a bureaucratic organization is known as for not being appropriate for attracting and keeping ambitious and creative employees, and that is because there are regulations and rules that may prevent the generation of new ideas and limit the ability of employees to use sources of knowledge (Wallach, 1983). There are also many studies showing the relationship between bureaucratic culture and organizational commitment. According to Silverthorne (2004), organizations with bureaucratic culture have the lowest level of organization commitment. Brewer and Clippard (2002) showed that bureaucratic culture has a negative effect on organizational commitment. Lok and Crawford (1999) also suggested that a bureaucratic environment result in reducing employee commitment.

\subsubsection{Employee Empowerment}

Employee empowerment is essential for productivity, and the growth of any organization (Hunjra, UlHaq, Akbar, \& Yousaf, 2011). It is regarded as the increasing of employees' involvement in decision making, and removing boundaries between managers and their subordinates to increase performance (Meyerson \& Dewettinck, 2012). Empowerment was defined previously as providing a firm's employees with the authority to deal with their everyday job tasks and activities (Hanaysha, 2016a). Many studies have examined the relationship between employees' empowerment and organizational commitment. A study by Hanaysha (2016a) showed a positive relationship between employees' empowerment and organizational commitment, and this is demonstrated by the fact that an environment that encourages empowerment in the workplace will have a positive impact on organizational commitment. Gholami, Soltanahmadi, Pashavi, and Nekouei (2013) have found that employee empowerment have a positive relationship with organizational commitment.

\subsection{Organizational Commitment}

Organizational commitment is one of the most popular research topics in the field of organizational behavior, and the prior research about organizational behavior shows that scholars are trying to understand the nature, consequences, and predictors of organizational commitment (Hanaysha, 2016b). Organizational behavior research 
has increasingly sought to understand the determinants, theoretical basis, and effects of organizational commitment (Spanuth \& Wald, 2017). Furthermore, the nature of ideal employment relationship has changed recently, as employees are seeking to find lifelong employment (Breitsohl \& Ruhle, 2013). Organizational commitment reflects the commitment of employees to their organization (Yao, Qiu, \& Wei, 2019). Organizational commitment can also be explained as a psychological emotional state that describes an employee's identification with a firm (Allen \& Meyer, 1990). Organizational commitment is very important because employees' goals and needs have to dovetail with the organization's needs and goals to gain the best from employees (Devece, Palacios-Marqués, \& Pilar Alguacil, 2016). It has also been referred to as how strongly employees are involved in and identify with the organization (McCunn \& Gifford, 2014). Many researchers have discussed the positive aspects of organizational commitment and its effects on work productivity, motivation, turnover intention, and absenteeism, and that it is a powerful tool for employees and organizations to increase productivity and effectiveness (Kuvaas, 2006; Genevičiūtè-Janonienė \& Endriulaitienè, 2014). Also, there are some studies that focus on the negative effects of organizational commitment, stating that, in some cases, it might impede the personal and social function of employees, as well as the organization (Genevičiūtè-Janonienė \& Endriulaitienè, 2014). According to Meyer and Allen (1991), there are three different dimensions of organizational commitment that need to be studied: continuance commitment, affective commitment, and normative commitment.

\subsubsection{Affective Commitment}

Affective commitment refers to affective attitudes toward the organization (Liu \& Bellibas, 2018). The affective component refers to when employees are emotionally attached to, involved in the organization (Huey Yiing $\&$ Zaman Bin Ahmad, 2009). Most of the researcher in the area of organizational commitment has focused on affective commitment (Brunetto \& Farr-Wharton, 2003). Affective commitment is a unique type of commitment that is useful for the organization and the employees, and it has been identified as a predictor to highly relevant outcomes in the organization, such as absenteeism, intention to leave, or work performance (Breitsohl \& Ruhle, 2013). Between the three types of commitment, affective commitment has the largest benefit to the organization, and it is also related to desirable work behavior (Fernandez-Lores, Gavilan, Avello, \& Blasco, 2016).

\subsubsection{Continuance Commitment}

Continuance commitment refers to commitment based on the costs that the employee associates with leaving the organization (Huey Yiing \& Zaman Bin Ahmad, 2009). The employees' bond with the firm while working in it over time, based on the personal investment that the employee makes, is the continuance commitment (Allen \& Meyer, 1990). This investment represents "sunken cost" (Becker, 1960). Sunken cost represents anything that the employee has invested that is important, such as time, money, and effort, which he would lose if he left the organization (Wallace, 1997). Continuance commitment reflects when employees feel that they are locked in certain place because of the high costs of leaving (Jaros, Jermier, Koehler, \& Sincich, 1993). Continuance commitment may appear for many reasons: for example, the high costs (training, salary, difficulty in finding a new job) appeared in the case of leaving the current job and the firm; therefore, employees in organizations stay for a longer period because they believe that a better job alternative is not available (Cak1, Asfuroglu, \& Erbas, 2015).

\subsubsection{Normative Commitment}

The normative commitment component refers to an employee's feeling of obligation to remain in the organization (Huey Yiing \& Zaman Bin Ahmad, 2009). In the 1980s, Wiener conducted several studies that described organizational commitment with a normative view. Wiener (1982) argued that employees with normative commitment are willing to make personal sacrifices for their firm because they believe that this is the wright and moral thing to do. He also argued that normative commitment is a result of familial cultural and socialization in the organization (Wiener, 1982). Measures of normative commitment had taken so many different forms, this situation led to difficulties in the findings of the research related to this concept (Meyer \& Parfyonova, 2010).

\subsection{Organizational Culture and Organizational Commitment}

There are many studies investigating the relationship between organizational culture and organizational commitment that show that there is a positive relationship between organizational culture and organizational commitment (Acar, 2012; Brewer \& Clippard, 2002). Organizational culture has been identified as a major driver behind employee longevity (Desselle, Raja, Andrews, \& Lui, 2018). Corporate culture is a significant tool for improving organizational commitment, and the better the adjustment between stated and perceived values, the better the organizational commitment (Brewer \& Clippard, 2002). One study applied to the Turkish logistics 
industry surveyed 344 employees, with the results showing that there is a positive relationship between organizational culture and organizational commitment (Acar, 2012). Shim, Jo, and Hoover (2015) showed that officers that were committed to a group culture were more committed to their organizations, with the study applied to 385 Korean police officers. Messner (2013) also found that there was a positive relationship between organizational culture and organizational commitment, recommending the design of a corporate culture change strategy, in order to increase organizational commitment in India's IT services.

\section{Research Methodology}

\subsection{Introduction}

This chapter addresses the research model, research hypotheses, operational definitions of the research variable, research population and sample, data collection methods, data analysis methods, descriptive statistics of the research sample, research validity and reliability and normality test is also carried out.

\subsection{Theoretical Framework}

The main purpose of this research is to examine the relationship between organizational culture and organizational commitment. Therefore, organizational culture is the independent variable, organizational commitment is the dependent variable. The researcher developed this research model based on the following studies: (Shahzad et al., 2017; Erdogan and Yildirim, 2017).

\section{Research Model}

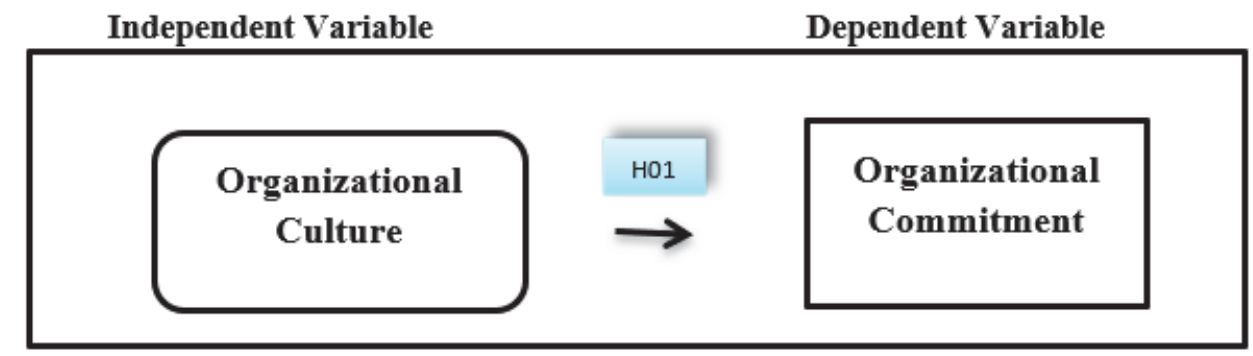

Figure 1. Research Model

\subsection{Research Hypotheses}

Based on the literature review and the underlying theoretical framework, testable hypothesis has been generated to examine the relationship between organizational culture and organizational commitment. In this research, the main hypothesis is as follows:

H01: There is no statistically significant relationship between organizational culture and organizational commitment.

\subsection{Operational Definitions}

This section defines the variables presented in the research model. Operational definitions of the research variable are as follows:

\subsubsection{Independent Variable: Organizational Culture}

Organizational culture was measured on the basis of four dimensions: using Wallach's (1983) scale of three dimensions, i.e., supportive culture, innovative culture, and bureaucratic culture; and one other dimension from Shahzad et al.'s (2017) scale, i.e., employee empowerment. The following dimensions measured for organizational culture:

- Supportive Culture

Supportive culture was measured on the basis of five items: teamwork, cohesiveness, participation, harmonious interpersonal relationships, and a sense of family (Ismail Ababaneh, 2010).

- Innovative Culture

Innovative culture was measured by five items referring to new ideas, risk taking, and experimentation (Ismail Ababaneh, 2010). 
- Bureaucratic Culture

Bureaucratic culture was measured on the basis of five items, referring to formalized, structured place, clear lines of responsibility and authority, lack of flexibility and formal rules and procedures (Ismail Ababaneh, 2010).

- Employee Empowerment

Employee empowerment is regarded as the increasing of employees' involvement in decision making, and removing boundaries between managers and their subordinates to increase performance, which was measured on the basis of four items, referring to increasing participation, involvement in decision making, and removing boundaries between managers and employees (Shahzad et al., 2017).

\subsubsection{Dependent Variable: Organizational Commitment}

Organizational commitment is how strongly employees are involved in and identify with the organization. According to Meyer and Allen's (1991) scale, there are three different components of organizational commitment: continuance commitment, affective commitment, and normative commitment. The following dimensions were measured for organizational commitment:

- Continuance Commitment

Continuance commitment was measured by four items, referring to employees' organizational involvement and commitment due to the perceived costs he or she would suffer from leaving the organization (Boichuk \& Menguc, 2013).

- $\quad$ Affective Commitment

Affective commitment was measured on the basis of five items, referring to the emotional connection between an employee and their organization (Boichuk \& Menguc, 2013).

- Normative Commitment

Normative commitment was measured on the basis of five items, referring to an employee's feeling of obligation toward a specific organization (Wasti \& Can, 2008).

\subsection{Research Population and Sample}

The research population is made up of the IT companies located in Jordan. According to the Amman Chamber of Commerce, there are currently about 650 well-established companies in the IT sector in Jordan. According to the Information and Communications Technology Association-Jordan (Intaj), total employee numbers in IT Companies in Jordan is 11,023 . The sample was extracted using convenience sampling because the sample was taken from companies that were easy to access, contact, and reach, and companies that were available and willing to participate. Almost 711 questionnaires were distributed among IT companies in Jordan, it was distributed to all employees from all management levels; 371 questionnaires were received back, 29 of the returned questionnaires were invalid, and 342 of the valid questionnaires were analyzed.

\subsection{Data Collection Methods}

Primary data were collected using self-administered questionnaires distributed to employees among IT companies in Jordan. The scale used in this research is a five-point Likert Scale ranging from strongly disagree to strongly agree. The questionnaire consists of three parts, the first being a short cover letter explaining the objective of the research and confirming the confidentiality of the responses. The second part collects demographic data, including gender, age, educational level, work experience, job position, and years worked in the company. The third part includes the main questionnaire consisting of 33 items, allowing respondents to express how much they agree or disagree with each statement. Secondary data were collected from books, journals, and articles.

\subsection{Data Analysis Methods}

The research utilized SPSS (Statistical Package for the Social Sciences) to analyze the data. The characteristics of the sample were analyzed through descriptive statistics. Regression analysis was used to test the research hypothesis.

\subsection{Descriptive Statistics of the Research Sample}

The research sample consisted of 371 employees who answered the questionnaire, resulting in a response rate of 52 percent. Demographic data, such as gender, age, educational level, work experience, job position, and years worked in the company, were the second part of the questionnaire. Descriptive analysis, such as frequencies and 
percentages, was carried out for this part of the research. Table 1 presents the results of this analysis.

Table 1. Characteristics of the Research Sample

\begin{tabular}{|c|c|c|c|}
\hline \multirow[t]{2}{*}{ Demographics } & \multirow[t]{2}{*}{ Categories } & & \multirow[b]{2}{*}{ Percent } \\
\hline & & Frequencies & \\
\hline \multirow[t]{2}{*}{ Gender } & Male & 211 & 61.7 \\
\hline & Female & 130 & 38.0 \\
\hline \multirow[t]{4}{*}{ Age } & 20-less than 30 & 209 & 61.1 \\
\hline & 30 -less than 40 & 111 & 32.5 \\
\hline & 40 -less than 50 & 17 & 5.0 \\
\hline & 50 and more & 5 & 1.5 \\
\hline \multirow[t]{5}{*}{ Educational Level } & Diploma & 29 & 8.5 \\
\hline & Higher Diploma & 6 & 1.8 \\
\hline & Bachelor & 286 & 83.6 \\
\hline & Master & 19 & 5.6 \\
\hline & Doctorate & 2 & 0.6 \\
\hline \multirow[t]{4}{*}{ Work Experience } & Less than 5 & 161 & 47.1 \\
\hline & 5-less than 10 & 98 & 28.7 \\
\hline & 10-less than 15 & 53 & 15.5 \\
\hline & 15 and more & 30 & 8.8 \\
\hline \multirow[t]{5}{*}{ Job Position } & Employee & 230 & 67.3 \\
\hline & Supervisor & 30 & 8.8 \\
\hline & Head of Department & 20 & 5.8 \\
\hline & Manager & 43 & 12.6 \\
\hline & Other & 19 & 5.6 \\
\hline \multirow[t]{4}{*}{ Years worked in the Company } & Less than a year & 91 & 26.6 \\
\hline & 1-less than 5 years & 157 & 45.9 \\
\hline & 5-less than 10 years & 70 & 20.5 \\
\hline & More than 10 years & 24 & 7.0 \\
\hline
\end{tabular}

Table 1 includes the frequencies and percentages of each demographic data, with the first results showing that the number of male employees exceeds the number of females due to the nature of the companies that the researcher was targeting. An overall 61.1 percent of the employees were aged from 20 to 30 years, which reflects that employees of this age were more cooperative and willing to help; it also means that IT companies tend to hire younger people at this domain. At the educational level, 83.6 percent of the employees held Bachelor's degrees, which is normal and the main requirement of most companies in every domain. Results show that 47.1 percent of the employees have less than 5 years' experience, meaning that IT Companies are focusing more on hiring fresh graduate students. A total of 67.3 percent of the employees held employee job positions, and 45.9 percent of the employees had 1 to less than 5 years worked in the company, which makes sense as the majority of the employees were aged from 20 to 30 years.

\subsection{Research Validity and Reliability}

Seskaran and Bougie (2016) assessed the importance of using a better instrument that will ensure more accuracy in results and enhance the quality of the research; so the researcher needed to assess the goodness of the measure that was developed and, therefore, the testing reliability and validity. It should be noted that the validity of an instrument is connected to its reliability. 


\subsubsection{Research Validity}

Validity is a test of how well an instrument measures the particular concept it is measuring (Seskaran \& Bougie, 2016). There are several types of validity; the first type is content validity, which ensures that the measure includes a representative and adequate set of items that tap the concept (Seskaran \& Bougie, 2016). The more the scale items represent the domain being measured, the greater the content validity (Seskaran \& Bougie, 2016). Face validity is a component of content validity, and it indicates that the items intended to measure the concept look like they measure the concept on the face of it (Seskaran \& Bougie, 2016). Another type of validity is construct validity, which represents how well the results acquired from the use of the measure fit the theories designed for the test (Seskaran \& Bougie, 2016). Factor analysis has been used to test construct validity. Factor analysis is a multivariate statistical approach commonly used in education, psychology, and in the health professions (Williams, Onsman, \& Brown, 2010). Exploratory factor analysis is a class of factor analysis. For conducting factor analysis, three assumptions must be met. First, the eigenvalue must be above 1. Second, Kaiser-Meyer-Olkin (KMO) must be above 0.50 , and finally, factor loading for all items must be above 0.40 (Hair, Black, Babin, Anderson, \& Tatham, 2010). For organizational culture, as shown in Table 2, the KMO value was .909 , which is greater than 0.50 , the eigenvalue for all items was above 1 , and factor loading for all items was above 0.40 . Therefore, none of the items were dropped from the scale used to measure organizational culture.

Table 2. Validity for Organizational Culture

\begin{tabular}{|c|c|c|c|c|}
\hline Items No. & $\begin{array}{l}\text { Bureaucratic } \\
\text { Culture }\end{array}$ & Innovative Culture & $\begin{array}{l}\text { Supportive } \\
\text { Culture }\end{array}$ & Employee Empowerment \\
\hline 1 & .746 & & & \\
\hline 2 & .804 & & & \\
\hline 3 & .679 & & & \\
\hline 4 & .810 & & & \\
\hline 5 & .643 & & & \\
\hline 6 & & .571 & & \\
\hline 7 & & .864 & & \\
\hline 8 & & .902 & & \\
\hline 9 & & .882 & & \\
\hline 10 & & .842 & & \\
\hline 11 & & & .725 & \\
\hline 12 & & & .837 & \\
\hline 13 & & & .852 & \\
\hline 14 & & & .733 & \\
\hline 15 & & & .690 & \\
\hline 16 & & & & .763 \\
\hline 17 & & & & .791 \\
\hline 18 & & & & .785 \\
\hline 19 & & & & .715 \\
\hline Initial Eigenvalues & 2.734399 & 3.372888 & 2.964374 & 2.336477 \\
\hline $\begin{array}{l}\text { Percentage of } \\
\text { Variance }\end{array}$ & 54.687972 & 67.457763 & $\mathbf{5 9 . 2 8 7 4 7 6}$ & 58.411925 \\
\hline
\end{tabular}

For organizational commitment, as shown in Table 3, the KMO value was .884, which is greater than 0.50 , the eigenvalue for all items was above 1 , and factor loading for all items was above 0.40 . Also, none of the items were dropped from the scale used to measure organizational commitment.

Table 3. Validity for Organizational Commitment

\begin{tabular}{ccccc}
\hline Items No. & $\begin{array}{c}\text { Affective } \\
\text { Commitment }\end{array}$ & $\begin{array}{c}\text { Continuance } \\
\text { Commitment }\end{array}$ & Normative & Commitment \\
\hline 20 & .816 & & \\
21 & .804 & & \\
& & & \\
\hline
\end{tabular}




\begin{tabular}{cccc}
22 & .826 & & \\
23 & .644 & & \\
24 & .816 & .768 & \\
25 & & .558 & \\
26 & & .884 & \\
27 & & .800 & .733 \\
28 & & & .546 \\
29 & & & .843 \\
30 & & & .892 \\
31 & & & .860 \\
32 & $\mathbf{3 . 0 7 5 7 6}$ & $\mathbf{2 . 3 2 1 3 3 9}$ & $\mathbf{3 . 0 8 7}$ \\
33 & & $\mathbf{5 8 . 0 3 3 4 6 7}$ & \\
\hline Initial Eigenvalues & & & \\
\hline Percentage & of & $\mathbf{6 1 . 5 1 5 3 1 4}$ & \\
Variance & & & \\
\hline
\end{tabular}

\subsubsection{Research Reliability}

Reliability is a test of how consistently a measuring instrument measures whatever is being measured; it indicates the extent to which it is error free and without bias, and offers an indication of the consistency and stability with which the instrument measures the concept (Seskaran \& Bougie, 2016). Cronbach's alpha is the most commonly used measure of reliability. When items are conducted to form a scale, they should have internal consistency. The items must all measure the same thing, so they have to be correlated with one another (Bland \& Altman, 1997).

The results of Cronbach's alpha are in Table 4 . There are different opinions about the acceptable values of alpha, ranging from 0.70 to 0.95 (Tavakol \& Dennick, 2011). The results show that all the variables have met the Cronbach's alpha rule $0.95 \geq \alpha \geq 0.70$ that is highly internally consistent.

Table 4. Reliability Coefficients of the Research Variables

\begin{tabular}{llcc}
\hline Variables & Dimensions & $\begin{array}{c}\text { Cronbach's Alpha } \\
\text { Value }\end{array}$ & Number of Items \\
\hline Independent Variable & & .858 & 19 \\
Organizational Culture & Bureaucratic Culture & .789 & 5 \\
& Innovative Culture & .876 & 5 \\
& Supportive Culture & .821 & 5 \\
& Employee & .758 & 4 \\
Empowerment & & \\
Dependent Variable & & .857 & 14 \\
Organizational & & .836 & 5 \\
Commitment & Affective Commitment & .702 & 4 \\
& Continuance & .765 & 5 \\
& Commitment & & 5 \\
& Normative & & \\
& Commitment & & \\
\hline
\end{tabular}

\subsection{Normality Test}

Normality is the assumption that the data follow a normal distribution (Driscoll, Lecky, \&Crosby, 2000). The principal test for the estimation of normality is the Kolmogorov-Smirnov (K-S) test. It suggests that the p-value should be greater than 0.05 , which indicates data is normally distributed (Elliott \& Woodward, 2007). Table 5 shows that only organizational commitment variable data are normally distributed when the researcher tested normality for each variable. Table 5 also shows that the data for all research variables are not normally distributed because the significant value is less than 0.05 . In large sample sizes ( $>30$ or 40$)$, the violation of the normality assumption should not cause serious problems (Pallant, 2007). With large samples ( $>30$ or 40$)$, regardless of the 
shape of the data, the sampling distribution tends to be normal (Field, 2009). Figure 2 shows the normal distribution curve.

Table 5. Normality Test Kolmogorov-Smirnov ${ }^{\mathrm{a}}$

\begin{tabular}{lccc}
\hline Dimensions & Statistic & df & Sig. \\
\hline Organizational Culture & .100 & 342 & .000 \\
$\begin{array}{l}\text { Organizational } \\
\text { Commitment }\end{array}$ & .044 & 342 & $.200^{*}$ \\
All Data & .105 & 342 & .000 \\
\hline
\end{tabular}

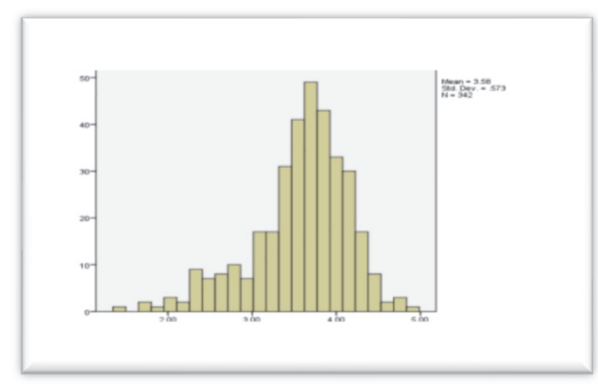

Figure 2. The Normal Distribution Curve

\section{Research Results}

\subsection{Introduction}

This chapter consists of the results of the statistical analysis of the data collected to answer the research question and to test the main hypothesis.

\subsection{Answers to the Research Questions}

Before testing the hypothesis, mean and standard deviation were computed. The mean, or the average, is a measure of central tendency and standard deviation is a measure of dispersion (Sekaran \& Bougie, 2016). The rank is the relative importance and is specified based on the following. from 0 to 2.66 is low, from 2.67 to 3.66 is medium, and from 3.67 to 5 is high (Alnuaimi, 2013). Tables 6 and 7 show the mean and standard deviation, as well as the ranking for all the research variables.

Table 6. Mean and Standard Deviation for Organizational Culture

\begin{tabular}{lccc}
\hline Dimensions & Mean & $\begin{array}{c}\text { Std. } \\
\text { Deviation }\end{array}$ & Rank \\
\hline Bureaucratic culture & 3.1468 & .85547 & Medium \\
Innovative Culture & 3.5637 & .87217 & Medium \\
Supportive Culture & 3.8357 & .76921 & High \\
Employee Empowerment & 3.5651 & 1.03050 & Medium \\
\hline General & 3.5848 & .56890 & Medium \\
\hline
\end{tabular}

Table 6 also shows that supportive culture has a mean of 3.8357, which is the highest mean compared to the other dimensions of organizational culture. Employee empowerment and innovative culture have very close means of 3.5651 and 3.5637, respectively. It also shows that bureaucratic culture has the lowest mean, 3.1468, indicating that IT companies in Jordan have a medium level of organizational culture. 
Table 7. Mean and Standard Deviation for Organizational Commitment

\begin{tabular}{lccc}
\hline Dimensions & Mean & $\begin{array}{c}\text { Std. } \\
\text { Deviation }\end{array}$ & Rank \\
\hline Affective Commitment & 3.7298 & .82298 & High \\
Continuance Commitment & 3.3852 & 1.08719 & Medium \\
Normative Commitment & 3.2468 & 1.11557 & Medium \\
General & 3.4539 & .80216 & Medium \\
\hline
\end{tabular}

Table 7 shows that affective commitment has the highest mean at 3.7298, then, continuance commitment comes next with a 3.3852 mean, and normative commitment has the lowest mean at 3.2468 , compared to the other dimensions of organizational commitment, indicating that IT companies in Jordan have a medium level of organizational commitment.

\subsection{Hypotheses Testing Results}

In this section, the researcher tested the null hypothesis, with the null hypothesis rejected when the sig level was less than 0.05 , and the null hypothesis accepted where the sig level was above 0.05 . Since the model of the research contains one independent variable, simple linear regression was used to test the hypothesis.

H01: There is no statistically significant relationship between organizational culture and organizational commitment.

To test this hypothesis the researcher used simple linear regression to examine the relationship between organizational culture and organizational commitment in IT Companies in Jordan. Table 8 shows that there is a relationship between organizational culture and organizational commitment. Pearson coefficient correlation $\mathrm{R}$ is $.435^{\mathrm{a}}$ and $\mathrm{R}$ square value .189 , meaning the results indicate that organizational culture explains 18.9 percent of variance in organizational commitment.

Table 8. Model Summary (Organizational Culture and Organizational Commitment)

\begin{tabular}{cccc}
\hline $\mathbf{R}$ & R Square & Adjusted R Square & Std. Error of the Estimate \\
\hline $.435^{\mathrm{a}}$ & .189 & .187 & .72331 \\
\hline
\end{tabular}

In Table 9, the significance level is less than 0.05 , which leads to the rejection of the null hypothesis and the acceptance of the alternative hypothesis about the relationship between organizational culture and organizational commitment.

Table 9. Anova Results (Organizational Culture and Organizational Commitment)

\begin{tabular}{|c|c|c|c|c|c|}
\hline Model & $\begin{array}{l}\text { Sum of } \\
\text { Squares }\end{array}$ & df & $\begin{array}{l}\text { Mean } \\
\text { Square }\end{array}$ & $\mathbf{F}$ & Sig. \\
\hline Regression & 41.541 & 1 & 41.541 & 79.402 & $.000^{\mathrm{b}}$ \\
\hline Residual & 177.880 & 340 & .523 & & \\
\hline Total & 219.422 & 341 & & & \\
\hline
\end{tabular}

According to the result in table 10, organizational culture can predict a .614 increase in organizational commitment.

Table 10. Coefficients of Organizational Culture and Organizational Commitment

\begin{tabular}{llccc}
\hline Model & Unstandardized Coefficients & $\begin{array}{c}\text { Standardized } \\
\text { Coefficients }\end{array}$ & t & Sig. \\
\hline
\end{tabular}




\begin{tabular}{lrcccc} 
& B & \multicolumn{5}{c}{ Btd. Error } & Beta & \\
\hline (Constant) & 1.255 & .250 & & 5.021 & .000 \\
Culture & .614 & .069 & .435 & 8.911 & .000 \\
\hline
\end{tabular}

\section{Discussion}

\subsection{Introduction}

This chapter includes a discussion of the research results, practical implications, limitations, recommendations, and future research.

\subsection{Discussion}

The aim of this research is to examine the relationship between organizational culture (in terms of bureaucratic culture, innovative culture, supportive culture, employee empowerment), and organizational commitment (affective commitment, continuance commitment, and normative commitment) in IT companies in Jordan.

The results in the previous chapter showed that organizational culture has a positive relationship with organizational commitment, indicating that culture plays an important role in keeping employees. These findings support the findings mentioned in the literature review, as follows: Acar (2012) also showed that there is a positive relationship between organizational culture and organizational commitment. Brewer and Clippard (2002) discussed that organizational culture is a significant tool for improving organizational commitment. Shim et al. (2015) showed that officers committed to group culture are more committed to their organizations. Messner (2013) also suggested that there is a positive relationship between organizational culture and organizational commitment, and it also recommend designing a corporate culture change strategy in order to increase organizational commitment.

Previous research findings support that there is a relationship between organizational culture and organizational commitment. In addition, enough evidence has been provided by the research to support this relationship. Therefore, organizations that attempt to improve their employees' commitment need to make extra effort to build a strong organizational culture.

\subsection{Practical Implications}

IT companies in Jordan are facing an enormous challenge in achieving and sustaining success because of economic challenges and born global companies. Acquiring employees to do their best in their work in these circumstances is a huge challenge to IT organizations (Nohria et al., 2008). IT companies have to make extra effort to build the right organizational culture that places emphasis on support, teamwork, encouraging, offering a trusting work environment, and also emphasizing an innovative, creative, challenging work environment, and finally placing emphasis on employee empowerment in order to provide employees with more authority to help them deal with their daily work activities and. According to the literature review, IT companies need to avoid building a bureaucratic, hierarchical, compartmentalized, organized, systematic culture.

\subsection{Limitations}

Since this research examined the relationship between organizational culture and organizational commitment in IT companies in Jordan, the results might not be generalized for the IT companies in other countries, especially seeing as organizational culture can be affected by a country's culture. Most of the large-sized IT companies refused to cooperate and be a part of this research, and the IT companies that were willing to cooperate were small- to medium-sized companies. All of the IT companies that accepted the offer to be a part of this research accepted a certain number of questionnaires, without a certain proportion being allocated to each company. The researcher faced difficulties in finding older respondents, with most of the respondents being in the younger category of 20 to less than 30 years of age.

\subsection{Recommendations and Future Research}

Since the unique contribution of this research is to study the relationship between organizational culture and organizational commitment in IT companies in Jordan, and because there is little research into this topic in IT companies, the researcher focused on certain dimensions other than those used by researchers in other research related to this topic. IT companies need to focus more on these aspects and apply them more with 
their employees. It may help companies to build the right culture and, therefore, achieve a higher level of commitment.

The researcher recommends using job satisfaction as a mediating variable, and to study whether job satisfaction can mediate the relationship between organizational culture and organizational commitment.

The researcher also recommends that future research should apply this research to various sectors rather than IT Companies or perhaps apply it to the whole ICT sector (Information and Communications Technology).

\section{Conclusion}

The main purpose of this research was to examine the relationship between organizational culture and organizational commitment in Information Technology Companies in Jordan. The most important conclusions that can be reached from this research are that organizational culture is an important predictor to organizational commitment in IT Companies in Jordan.

As a conclusion the researcher has answers toward examining the relationship between organizational culture and organizational commitment in Information Technology Companies in Jordan and the suggested hypothesis is supported by rejection of the null hypothesis. Therefore IT Companies should take into considerations these variables to enhance their work.

\section{References}

Abdul Rashid, Z., Sambasivan, M., \& Johari, J. (2003). The influence of corporate culture and organisational commitment on performance. Journal of management development, 22(8), 708-728. https://doi.org/10.1108/02621710310487873

Abdullah, A., \& Ramay, I. (2012). Antecedents of organizational commitment of banking sector employees in Pakistan. Serbian Journal of Management, 7(1), 89-102. https://doi.org/10.5937/sjm1201089a

Acar, A. Z. (2012). Organizational culture, leadership styles and organizational commitment in Turkish logistics $\begin{array}{llll}\text { industry. } \quad \text { Procedia-Social and Behavioral } & \text { Sciences, }\end{array}$ https://doi.org/10.1016/j.sbspro.2012.09.995

Adachi, B., Helfrich, D., Gretczko, M., \& Schwartz, J. (2012). Human Capital Trends 2012: Leap Ahead. Mumbai: Deloitte Human Capital.

Ahmady, G. A., Nikooravesh, A., \& Mehrpour, M. (2016). Effect of organizational culture on knowledge management based on Denison model. Procedia-Social and Behavioral Sciences, 230, 387-395. https://doi.org/10.1016/j.sbspro.2016.09.049

Allen, N., \& Meyer, J. (1990). The measurement and antecedents of affective, continuance and normative commitment to the organization. Journal of Occupational Psychology, 63(1), 1-18. https://doi.org/10.1111/j.2044-8325.1990.tb00506.x

Alnuaimi, M. (2013). Applies Statistics. Dar Wael for Publishing and Distribution.

Al-Sada, M., Al-Esmael, B., \& Faisal, M. N. (2017). Influence of organizational culture and leadership style on employee satisfaction, commitment and motivation in the educational sector in Qatar. EuroMed Journal of Business, 12(2), 163-188. https://doi.org/10.1108/emjb-02-2016-0003

Arditi, D., Nayak, S., \& Damci, A. (2017). Effect of organizational culture on delay in construction. International Journal of Project Management, 35(2), 136-147. https://doi.org/10.1016/j.ijproman.2016.10.018

Becker, H. S. (1960). Notes on the concept of commitment. American journal of Sociology, 66(1), 32-40. https://doi.org/10.1086/222820

Bellou, V. (2010). Organizational culture as a predictor of job satisfaction: the role of gender and age. Career Development International, 15(1), 4-19. https://doi.org/10.1108/13620431011020862

Berson, Y., Oreg, S., \& Dvir, T. (2008). CEO values, organizational culture and firm outcomes. Journal of Organizational Behavior, 29(5), 615-633. https://doi.org/10.1002/job.499

Bettenhausen, K., \& Murnighan, J. K. (1985). The emergence of norms in competitive decision-making groups. Administrative science quarterly, 350-372. https://doi.org/10.2307/2392667

Bland, J. M., \& Altman, D. G. (1997). Statistics notes: Cronbach's alpha. Bmj, 314(7080), 572. https://doi.org/10.1136/bmj.314.7080.572 
Boichuk, J. P., \& Menguc, B. (2013). Engaging dissatisfied retail employees to voice promotive ideas: The role of continuance commitment. Journal of retailing, 89(2), 207-218. https://doi.org/10.1016/j.jretai.2013.01.001

Breitsohl, H., \& Ruhle, S. (2013). Residual affective commitment to organizations: Concept, causes and consequences. Human Resource Management Review, 23(2), 161-173. https://doi.org/10.1016/j.hrmr.2012.07.008

Brewer, E. W., \& Clippard, L. F. (2002). Burnout and job satisfaction among student support services personnel. Human Resource Development Quarterly, 13(2), 169-186. https://doi.org/10.1002/hrdq.1022

Brunetto, Y., \& Farr-Wharton, R. (2003). The commitment and satisfaction of lower-ranked police officers: Lessons for management. Policing: An International Journal of Police Strategies \& Management, 26(1), 4363. https://doi.org/10.1108/13639510310460297

Burke, C. S., Sims, D. E., Lazzara, E. H., \& Salas, E. (2007). Trust in leadership: A multi-level review and integration. The Leadership Quarterly, 18(6), 606-632. https://doi.org/10.1016/j.leaqua.2007.09.006

Cak1, N., Asfuroglu, L., \& Erbas, O. (2015). The Relationship between the Level of Attachment in Romantic Relations, Affective Commitment and Continuance Commitment towards Organization: A Field Research. Procedia Economics and Finance, 26, 1007-1013. https://doi.org/10.1016/s2212-5671(15)00923-5

Cameron, K. S., \& Ettington, D. R. (1988). The conceptual framework of organizational culture. Higher education: Handbook of theory and research, 6, 356-396.

Cameron, K. S., \& Quinn, R. E. (2011). Diagnosing and changing organizational culture: Based on the competing values framework. John Wiley \& Sons.

Deshpandé, R., \& Farley, J. (2004). Organizational culture, market orientation, innovativeness, and firm performance: an international research odyssey. International Journal of Research in Marketing, 21(1), 3-22. https://doi.org/10.1016/j.jiresmar.2003.04.002

Desselle, S. P., Raja, L., Andrews, B., \& Lui, J. (2018). Perceptions of organizational culture and organizational citizenship by faculty in US colleges and schools of pharmacy. Currents in Pharmacy Teaching and Learning, 10(4), 403-412. https://doi.org/10.1016/j.cptl.2017.12.017

Devece, C., Palacios-Marqués, D., \& Pilar Alguacil, M. (2016). Organizational commitment and its effects on organizational citizenship behavior in a high-unemployment environment. Journal of Business Research, 69(5), 1857-1861. https://doi.org/10.1016/j.jbusres.2015.10.069

Dey, T., Kumar, A., \& Kumar, Y. L. N. (2014). A new look at the antecedents and consequences of organizational commitment: a conceptual study. International Journal of Humanities and Social Science, 4(1), 281-287.

Driscoll, P., Lecky, F., \& Crosby, M. (2000). An introduction to statistical inference-3. Emergency Medicine Journal, 17(5), 357-363.

Elliott, A. C., \& Woodward, W. A. (2007). Statistical analysis quick reference guidebook: With SPSS examples. Sage. https://doi.org/10.4135/9781412985949

Erdogan, V., \& Yildirim, A. (2017). Healthcare professionals' exposure to mobbing behaviors and relation of mobbing with job satisfaction and organizational commitment. Procedia Computer Science, 120, 931-938 https://doi.org/10.1016/j.procs.2017.11.328

Fernandez-Lores, S., Gavilan, D., Avello, M., \& Blasco, F. (2016). Affective commitment to the employer brand: Development and validation of a scale. BRQ Business Research Quarterly, 19(1), 40-54. https://doi.org/10.1016/j.brq.2015.06.001

Field, A. (2009). Discovering statistics using SPSS. Sage publications.

Garson, G. D. (2015). Missing values analysis and data imputation. Asheboro, NC: Statistical Associates Publishing Asheboro.

Genevičiūtė-Janonienė, G., \& Endriulaitienè, A. (2014). Employees' Organizational Commitment: Its Negative Aspects for Organizations. Procedia - Social and Behavioral Sciences, 140, 558-564. https://doi.org/10.1016/j.sbspro.2014.04.470

Gholami, Z., Soltanahmadi, J. A., Pashavi, G., \& Nekouei, S. (2013). Empowerment as a basic step in upgrading organizational commitment and organizational citizenship behaviors: A Case study on public sector in Iran. World Applied Sciences Journal, 21(11), 1693-1698.

Hair, J. F., Black, W. C., Babin, B. J., Anderson, R. E., \& Tatham, R. L. (2010). Multivariate data analysis. Pearson. 
Hanaysha, J. (2016a). Examining the Effects of Employee Empowerment, Teamwork, and Employee Training on Organizational Commitment. Procedia - Social and Behavioral Sciences, 229, 298-306. https://doi.org/10.1016/j.sbspro.2016.07.140

Hanaysha, J. (2016b). Testing the Effects of Employee Engagement, Work Environment, and Organizational Learning on Organizational Commitment. Procedia - Social and Behavioral Sciences, 229, 289-297. https://doi.org/10.1016/j.sbspro.2016.07.139

Harper, G. R., \& Utley, D. R. (2001). Organizational culture and successful information technology implementation. Engineering Management Journal, 13 13(2), https://doi.org/10.1080/10429247.2001.11415111

Hofstede, G., Neuijen, B., Ohayv, D., \& Sanders, G. (1990). Measuring Organizational Cultures: A Qualitative and Quantitative Study Across Twenty Cases. Administrative Science Quarterly, 35(2), 286. https://doi.org/10.2307/2393392

Hogan, S. J., \& Coote, L. V. (2014). Organizational culture, innovation, and performance: A test of Schein's model. Journal of Business Research, 67(8), 1609-1621. https://doi.org/10.1016/j.jbusres.2013.09.007

Huey Yiing, L., \& Zaman Bin Ahmad, K. (2009). The moderating effects of organizational culture on the relationships between leadership behaviour and organizational commitment and between organizational commitment and job satisfaction and performance. Leadership \& Organization Development Journal, 30(1), 53-86. https://doi.org/10.1108/01437730910927106

Hunjra, A. I., Ul Haq, N., Akbar, S. W., \& Yousaf, M. (2011). Impact of employee empowerment on job satisfaction: an empirical analysis of Pakistani service industry. Interdisciplinary Journal of Contemporary Research in Business, 2(11), 680-685.

Ireland, R. D., Hitt, M. A., \& Sirmon, D. G. (2003). A model of strategic entrepreneurship: The construct and its dimensions. Journal of management, 29(6), 963-989. https://doi.org/10.1016/s0149-2063_03_00086-2

Ismail Ababaneh, R. (2010). The role of organizational culture on practising quality improvement in Jordanian public hospitals. Leadership in Health Services, 23(3), 244-259. https://doi.org/10.1108/17511871011061064

Jaros, S. J., Jermier, J. M., Koehler, J. W., \& Sincich, T. (1993). Effects of continuance, affective, and moral commitment on the withdrawal process: An evaluation of eight structural equation models. Academy of management Journal, 36(5), 951-9. https://doi.org/10.5465/256642

Joseph, O. \& Francis, K. (2015). The Influence of Organizational Culture and Market Orientation on Performance of Microfinance Institutions in Kenya. International Journal of Business and Management, 10(8). https://doi.org/10.5539/ijbm.v10n8p204

Khazanchi, S., Lewis, M. W., \& Boyer, K. K. (2007). Innovation-supportive culture: The impact of organizational values on process innovation. Journal of operations management, 25(4), 871-884. https://doi.org/10.1016/j.jom.2006.08.003

Kuvaas, B. (2006). Work performance, affective commitment, and work motivation: The roles of pay administration and pay level. Journal of Organizational Behavior, 27(3), 365-385. https://doi.org/10.1002/job.377

Kwantes, C. T. (2009). Culture, job satisfaction and organizational commitment in India and the United States. Journal of Indian Business Research, 1(4), 196-212. https://doi.org/10.1108/17554190911013265

Lapina, I., Kairiša, I., \& Aramina, D. (2015). Role of Organizational Culture in the Quality Management of University. Procedia - Social and Behavioral Sciences, 213, 770-774. https://doi.org/10.1016/j.sbspro.2015.11.472

Levering, R. B. (2016). The cold war: a post-cold war history. John Wiley \& Sons. pp. 365-374.

Liu, Y., \& Bellibas, M. S. (2018). School factors that are related to school principals' job satisfaction and organizational commitment. International Journal of Educational Research, 90, 1-19. https://doi.org/10.1016/j.jijer.2018.04.002

Lok, P., \& Crawford, J. (1999). The relationship between commitment and organizational culture, subculture, leadership style and job satisfaction in organizational change and development. Leadership \& Organization Development Journal, 20(7), 365-374. https://doi.org/10.1108/01437739910302524

McCunn, L. J., \& Gifford, R. (2014). Interrelations between sense of place, organizational commitment, and green 
neighborhoods. Cities, 41, 20-29. https://doi.org/10.1016/j.cities.2014.04.008

Messner, W. (2013). Effect of organizational culture on employee commitment in the Indian IT services sourcing industry. Journal of Indian Business Research, 5(2), 76-100. https://doi.org/10.1108/17554191311320764

Meyer, J., \& Allen, N. (1991). A three-component conceptualization of organizational commitment. Human Resource Management Review, 1(1), 61-89. https://doi.org/10.1016/1053-4822(91)90011-z

Meyer, J., \& Herscovitch, L. (2001). Commitment in the workplace: toward a general model. Human Resource Management Review, 11(3), 299-326. https://doi.org/10.1016/s1053-4822(00)00053-x

Meyer, J., \& Parfyonova, N. (2010). Normative commitment in the workplace: A theoretical analysis and reconceptualization. Human Resource Management Review, 20(4), 283-294. https://doi.org/10.1016/j.hrmr.2009.09.001

Meyerson, G., \& Dewettinck, B. (2012). Effect of empowerment on employees performance. Advanced Research in Economic and Management Sciences, 2(1), 40-46.

Morrow, P. C., McElroy, J. C., \& Scheibe, K. P. (2012). Influencing organizational commitment through office redesign. Journal of Vocational Behavior, 81(1), 99-111. https://doi.org/10.1016/j.jvb.2012.05.004

Nohria, N., Groysberg, B., \& Lee, L. E. (2008). Employee motivation: A powerful new model. Harvard Business Review, 86(7/8), 78-84.

Odom, R. Y., Boxx, W. R., \& Dunn, M. G. (1990). Organizational cultures, commitment, satisfaction, and cohesion. Public Productivity \&amp; Management Review, 157-169. https://doi.org/10.2307/3380963

O'Reilly, C. A., Chatman, J., \& Caldwell, D. F. (1991). People and organizational culture: A profile comparison approach to assessing person-organization fit. Academy of management journal, 34(3), 487-516. https://doi.org/10.5465/256404

Pallant, J. (2007). SPSS survival manual: A step by step guide to data analysis using SPSS.

Rasool, R., Ganai, B. A., Kamili, A. N., \& Akbar, S. (2012). Antioxidant potential in callus culture of Artemisia amygdalina Decne. Natural product research, 26(22), 2103-2106.

Schein, E. H. (1996). Culture: The missing concept in organization studies. Administrative science quarterly, 229240. https://doi.org/10.2307/2393715

Scholarios, D., Van der Heijden, B. I., Van der Schoot, E., Bozionelos, N., Epitropaki, O., Jedrzejowicz, P., \& Van der Heijde, C. M. (2008). Employability and the psychological contract in European ICT sector SMEs. The International Journal of Human Resource Management, 19(6), 1035-1055. https://doi.org/10.1080/09585190802051337

Sekaran, U., \& Bougie, R. (2016). Research methods for business: A skill building approach. John Wiley \& Sons.

Shahzad, F., Xiu, G., \& Shahbaz, M. (2017). Organizational culture and innovation performance in Pakistan's software industry. Technology in Society, 51, 66-73. https://doi.org/10.1016/j.techsoc.2017.08.002

Shim, H. S., Jo, Y., \& Hoover, L. T. (2015). Police transformational leadership and organizational commitment: Mediating role of organizational culture. Policing: An International Journal of Police Strategies \& Management, 38(4), 754-774. https://doi.org/10.1108/pijpsm-05-2015-0066

Silverthorne, C. (2004). The impact of organizational culture and person-organization fit on organizational commitment and job satisfaction in Taiwan. Leadership \& Organization Development Journal, 25(7), 592599. https://doi.org/10.1108/01437730410561477

Spanuth, T., \& Wald, A. (2017). Understanding the antecedents of organizational commitment in the context of temporary organizations: An empirical study. Scandinavian Journal of Management, 33(3), 129-138. https://doi.org/10.1016/j.scaman.2017.06.002

Stan, M. M. (2013). Predictors of the organizational commitment in the Romanian academic environment. Procedia-Social and Behavioral Sciences, 78, 672-676. https://doi.org/10.1016/j.sbspro.2013.04.373

Tavakol, M., \& Dennick, R. (2011). Making sense of Cronbach's alpha. International journal of medical education, 2, 53.

Tharikh, S. M., Ying, C. Y., \& Saad, Z. M. (2016). Managing job attitudes: the roles of job satisfaction and organizational commitment on organizational citizenship behaviors. Procedia Economics and Finance, 35, 604-611. https://doi.org/10.1016/s2212-5671(16)00074-5 
Wallace, J. (1997). Becker's Side-Bet Theory of Commitment Revisited: Is It Time for a Moratorium or a Resurrection? Human Relations, 50(6), 727-749. https://doi.org/10.1177/001872679705000605

Wallach, E. J. (1983). Individuals and organizations: The cultural match. Training \& Development Journal.

Warrick, D. (2017). What leaders need to know about organizational culture. Business Horizons, 60(3), 395-404. https://doi.org/10.1016/j.bushor.2017.01.011

Warrick, D., Milliman, J., \& Ferguson, J. (2016). Building high performance cultures. Organizational Dynamics, 45(1), 64-70. https://doi.org/10.1016/j.orgdyn.2015.12.008

Wasti, S. A., \& Can, Ö. (2008). Affective and normative commitment to organization, supervisor, and coworkers: Do collectivist values matter? Journal of Vocational Behavior, 73(3), 404-413. https://doi.org/10.1016/j.jvb.2008.08.003

Wiener, Y. (1982). Commitment in Organizations: A Normative View. The Academy of Management Review, 7(3), 418. https://doi.org/10.2307/257334

Williams, B., Onsman, A., \& Brown, T. (2010). Exploratory factor analysis: A five-step guide for novices. Australasian Journal of Paramedicine, 8(3). https://doi.org/10.33151/ajp.8.3.93

Yao, T., Qiu, Q., \& Wei, Y. (2019). Retaining hotel employees as internal customers: Effect of organizational commitment on attitudinal and behavioral loyalty of employees. International Journal of Hospitality Management, 76, 1-8. https://doi.org/10.1016/j.ijhm.2018.03.018

Zhang, M., \& Tansuhaj, P. S. (2007). Organizational culture, information technology capability, and performance: the case of born global firms. Multinational Business Review, 15(3), 43-78. https://doi.org/10.1108/1525383x200700012

\section{Appendix A}

\section{Research Population and Sample}

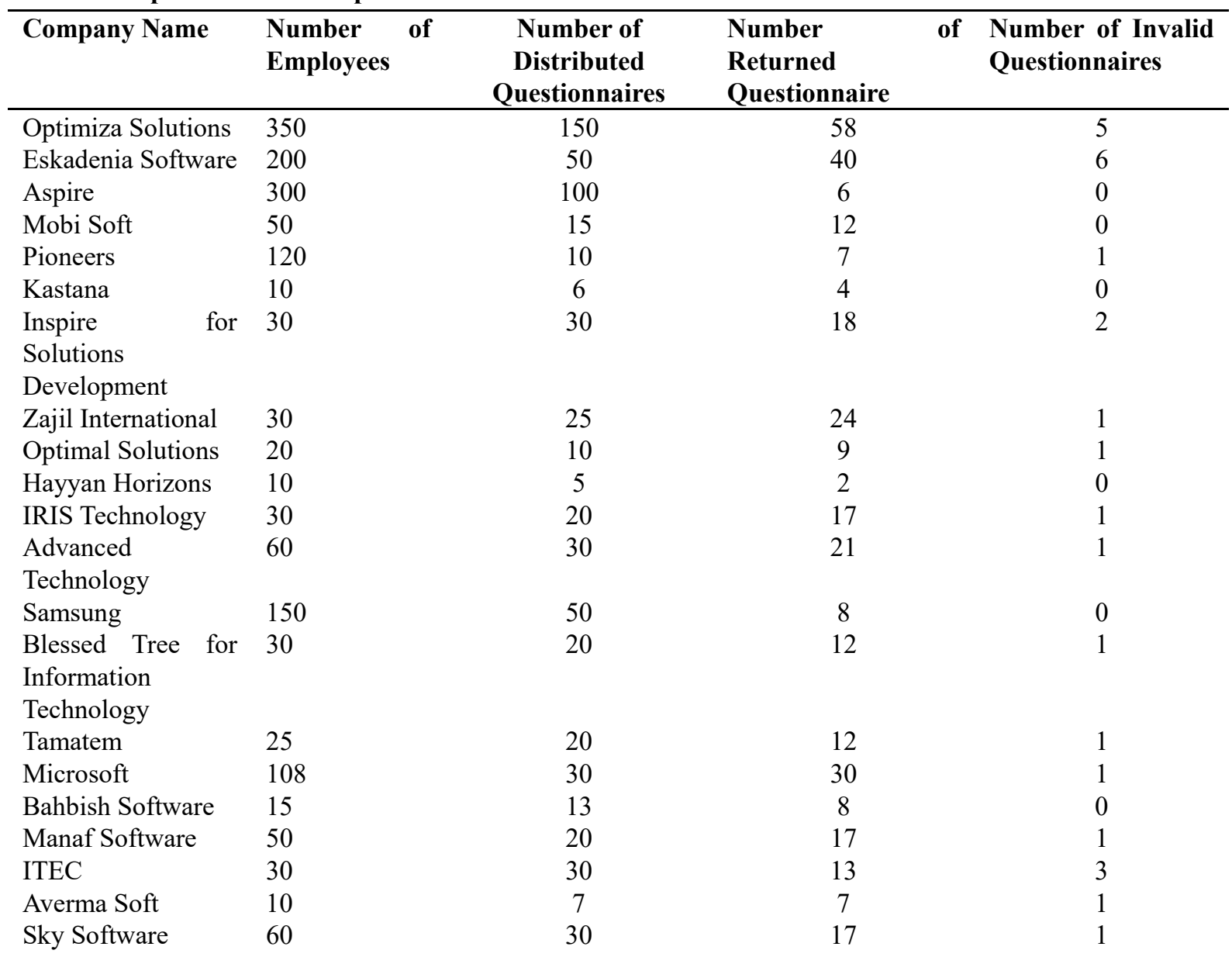




\begin{tabular}{llccc} 
ITAC & 35 & 20 & 15 & 0 \\
02 Code & 10 & 5 & 5 & 0 \\
Applexia & 20 & 15 & 9 & 2 \\
\hline Total & $\mathbf{1 7 5 3}$ & $\mathbf{7 1 1}$ & $\mathbf{3 7 1}$ & $\mathbf{2 9}$ \\
\hline
\end{tabular}

\section{Copyrights}

Copyright for this article is retained by the author(s), with first publication rights granted to the journal.

This is an open-access article distributed under the terms and conditions of the Creative Commons Attribution license (http://creativecommons.org/licenses/by/4.0/). 